\title{
Pyridines Bearing Poly(ethylene glycol) Chains: Synthesis and Use as Ligands
}

\section{$\operatorname{AUTHOR}(\mathrm{S})$ :}

Satou, Motoi; Kiyooka, Arata; Tsuji, Yasushi; Fujihara, Tetsuaki

\section{CITATION:}

Satou, Motoi ...[et al]. Pyridines Bearing Poly(ethylene glycol) Chains: Synthesis and Use as Ligands. Asian Journal of Organic Chemistry 2020, 9(5): 761-764

\section{ISSUE DATE:}

2020-05

URL:

http://hdl.handle.net/2433/261183

\section{RIGHT:}

This is the peer reviewed version of the following article: M. Satou, A. Kiyooka, Y. Tsuij, T. Fuijhara, Asian J. Org. Chem. 2020, 9, 761, which has been published in final form at https://doi.org/10.1002/ajoc.202000062. This article may be used for non-commercial purposes in accordance with Wiley Terms and Conditions for Use of Self-Archived Versions.; The full-text file will be made open to the public on 18 March 2021 in accordance with publisher's 'Terms and Conditions for Self-Archiving'.; この論文は出版社版でありません。引用の際には出版社版をご確認ご利用ください。; This is not the published version. Please cite only the published version. 


\title{
Pyridines Bearing Poly(ethylene glycol) Chains: Synthesis and Use as Ligands
}

\author{
Motoi Satou, Arata Kiyooka, Yasushi Tsuji and Tetsuaki Fujihara* \\ Dedication ((please delete if not required))
}

\author{
Dr. M. Satou, A. Kiyooka, Prof. Dr. Y. Tsuji, Prof. Dr. T. Fujihara \\ Department of Energy and Hydrocarbon Chemistry, Graduate School of Engineering \\ Kyoto University \\ Nishikyo-Ku, Kyoto 615-8510 \\ E-mail: tfuji@scl.kyoto-u.ac.jp
}

Supporting information for this article is given via a link at the end of the document.((Please delete this text if not appropriate))

\begin{abstract}
A series of pyridine ligands bearing poly(ethylene glycol) (PEG) chains at the para position was synthesized and characterized by NMR and ESI-HRMS analysis. ${ }^{1} \mathrm{H}$ NMR analysis showed that pyridines coordinate to $\mathrm{Pd}(\mathrm{OAc})_{2}$ even when a long $\mathrm{PEG}$ chain is attached to the pyridine ring. In the Pd-catalyzed oxidation of alcohols, the pyridines bearing longer PEG chains were found to be efficient ligands.
\end{abstract}

Transition metal-catalyzed reactions are powerful methodologies for synthesizing a diverse range of organic compounds. In these reactions, ligands play important roles in controlling catalytic activity as well as product selectivity. ${ }^{[1]}$ Therefore, the development of new ligands aimed at improving catalyst properties has been intensively studied. ${ }^{[2]}$ Poly(ethylene glycol) (PEG) and its derivatives are polymeric materials composing $\mathrm{CH}_{2} \mathrm{CH}_{2} \mathrm{O}$ - monomer units that are attractive materials owing to their amphiphilicity, low cost, low toxicity, and availability. ${ }^{[3]}$ Although the application of PEG to catalytic systems has been reported, the studies are mainly focused on their use in improving water solubility, ${ }^{[4]}$ controlling solubility for phase separation systems, ${ }^{[5]}$ or catalyst recycling. ${ }^{[6]}$ On the other hand, PEG is a unique functional group for ligands in homogeneous transition metal-catalyzed reactions in organic solvents. For instance, Chen et al. reported $\mathrm{Pd}$ - and $\mathrm{Ni}$-catalyzed copolymerization of ethylene and polar monomers with phosphine-sulfonate ligands bearing short PEG $\left(\left(\mathrm{CH}_{2} \mathrm{CH}_{2} \mathrm{O}\right)_{\mathrm{n}:} \mathrm{n}=2\right)$ chains. ${ }^{[7]}$ We have focused on the effects of flexible $P E G$ chains on ligands. ${ }^{[8-10]} A$ series of triaryl phosphines and $\mathrm{N}$-heterocyclic carbenes bearing PEG

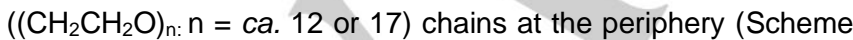
$1 \mathrm{a}, \mathrm{b})$ were synthesized and characterized. These ligands were demonstrated to work well in Pd-catalyzed Suzuki-Miyaura coupling reactions using less reactive aryl chlorides as substrates under mild reaction conditions. ${ }^{[8,9]}$

Pyridines are known to be as efficient ligands in various $\mathrm{Pd}$ catalyzed oxidative reactions since these are stable under the oxidative reaction conditions. ${ }^{[11]}$ We previously reported that a bulky and rigid pyridine ligand was highly effective for the Pdcatalyzed alcohol oxidation reactions. ${ }^{[12]}$ In the reactions, the bulkiness of the ligand successfully suppressed the formation of Pd black. Herein, we report the synthesis of a series of pyridines bearing a flexible PEG chain at the para position (1a-b) in order to reduce steric congestion around the coordination site (Scheme 1c). Regarding PEG-functionalized pyridines, Oberhauser and Frediani reported that a pyridine bearing very long PEG chain ( $\mathrm{n}$ $=c a$. 116) supported the formation of Pd nanoparticle and the particle worked as heterogeneous catalysts for the oxidation of alcohols in water. ${ }^{[13]}$ In the present study, we found that pyridines bearing PEG chains were effective as ligands in homogeneous $\mathrm{Pd}$-catalyzed oxidation of alcohols in toluene.

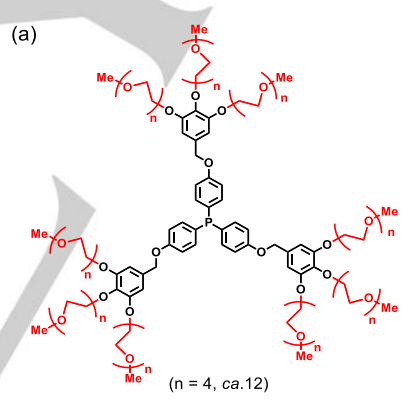

(b)

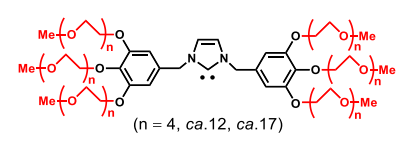

(c)

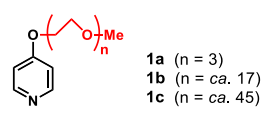

Scheme 1. PEG-functionalized ligands in our previous study. (a) Phosphines (b) N-heterocyclic carbenes, and (c) pyridines (This work).

First, a pyridine bearing a PEG chain $(\mathrm{n}=3, \mathbf{1 a})$ was synthesized by the reaction of 4-chloropyridine hydrochloride (2) with $\mathrm{HO}\left(\mathrm{CH}_{2} \mathrm{CH}_{2} \mathrm{O}\right)_{3} \mathrm{Me}(3 \mathrm{a})$ in the presence of $\mathrm{NaH}$ (Scheme 2) and $1 \mathrm{a}$ was isolated in $60 \%$ yield as colorless oil. For $\mathbf{1 b}$ with a longer PEG chain ( $\mathrm{n}=\mathrm{ca}$. 17), the same method used for 1a was adopted using $\mathrm{HO}\left(\mathrm{CH}_{2} \mathrm{CH}_{2} \mathrm{O}\right)_{n} \mathrm{Me}(\mathrm{n}=\mathbf{c a} .17, \mathbf{3 b})$ in place of $\mathbf{3} \mathbf{a}$, and the desired product $1 \mathrm{~b}$ was obtained in $66 \%$ yield as a pale yellow oil. Notably, a longer PEG chain was introduced via the method using $\mathrm{HO}\left(\mathrm{CH}_{2} \mathrm{CH}_{2} \mathrm{O}\right)_{n} \mathrm{Me}(\mathrm{n}=\mathrm{ca} .45,3 \mathrm{c})$, and $1 \mathrm{c}$ was successfully obtained in $41 \%$ yield as pale yellow powder by reprecipitation using $\mathrm{Et}_{2} \mathrm{O}$.

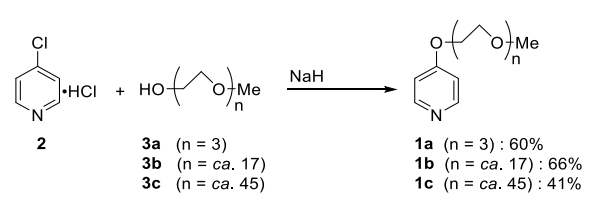


Scheme 2. Synthesis of pyridines 1a-1c.

Each pyridine was characterized by NMR and ESI-HRMS analysis. The ${ }^{1} \mathrm{H}$ and ${ }^{13} \mathrm{C}$ NMR spectra of $\mathbf{1 a}-1 \mathrm{c}$ are consistent with the expected structures. The ESI-HRMS spectrum of 1a features a peak at $m / z 242.1384$, which is assigned to the monoprotonated adduct of $1 \mathrm{a}\left(\mathrm{m} / z 242.1392\right.$ calcd for $\left.\mathrm{C}_{12} \mathrm{H}_{20} \mathrm{O}_{4} \mathrm{~N}\right)$. The mass spectrum of $\mathbf{1 b}$ shows a molecular weight distribution (Figure 1a). A set of peaks separated by $\mathrm{m} / \mathrm{z} 44$ intervals is observed, where $\mathrm{m} / \mathrm{z} 44$ corresponds to a $-\mathrm{CH}_{2} \mathrm{CH}_{2} \mathrm{O}$ - monomer unit. Therefore, these peaks were attributed to the monovalent ion. A peak at $m / z$ 858.5037, as indicated in Figure $1 \mathrm{a}$, is in good agreement with the calculated value for the proton adduct of $\mathbf{1 b}$ $\left(\mathrm{n}=17, \mathrm{~m} / \mathrm{z} 858.5062\right.$ calcd for $\left.\left[\mathrm{C}_{40} \mathrm{H}_{76} \mathrm{O}_{18} \mathrm{~N}\right]^{+}\right)$. In addition, the other set of peaks was attributed to the mono-sodium adduct of 1b (found: $m / z$ 880.4856; calcd: $m / z 880.4881\left[\mathrm{C}_{40} \mathrm{H}_{75} \mathrm{O}_{18} \mathrm{NNa}\right]^{+}$). On the other hand, $\mathbf{1 c}$ is observed mainly as divalent ions with $\mathrm{m} / \mathrm{z} 22$ intervals (Figure $1 \mathrm{~b}$ ). The peak at $\mathrm{m} / \mathrm{z}$ 1057.1121, as indicated in Figure $1 \mathrm{~b}$, is attributed to the proton-sodium adduct of $1 \mathrm{c}$ where $\mathrm{n}=45\left(\mathrm{~m} / \mathrm{z} 1057.1150\right.$ calcd for $\left.\left[\mathrm{C}_{96} \mathrm{H}_{188} \mathrm{O}_{46} \mathrm{NNa}\right]^{2+}\right)$. In addition, the disodium adducts of $1 \mathrm{c}$ are also observed (found: $\mathrm{m} / \mathrm{z} 1068.1028$ calcd $\left.\mathrm{m} / \mathrm{z} 1068.1060\left[\mathrm{C}_{96} \mathrm{H}_{187} \mathrm{O}_{46} \mathrm{NNa}_{2}\right]^{2+}\right)$.

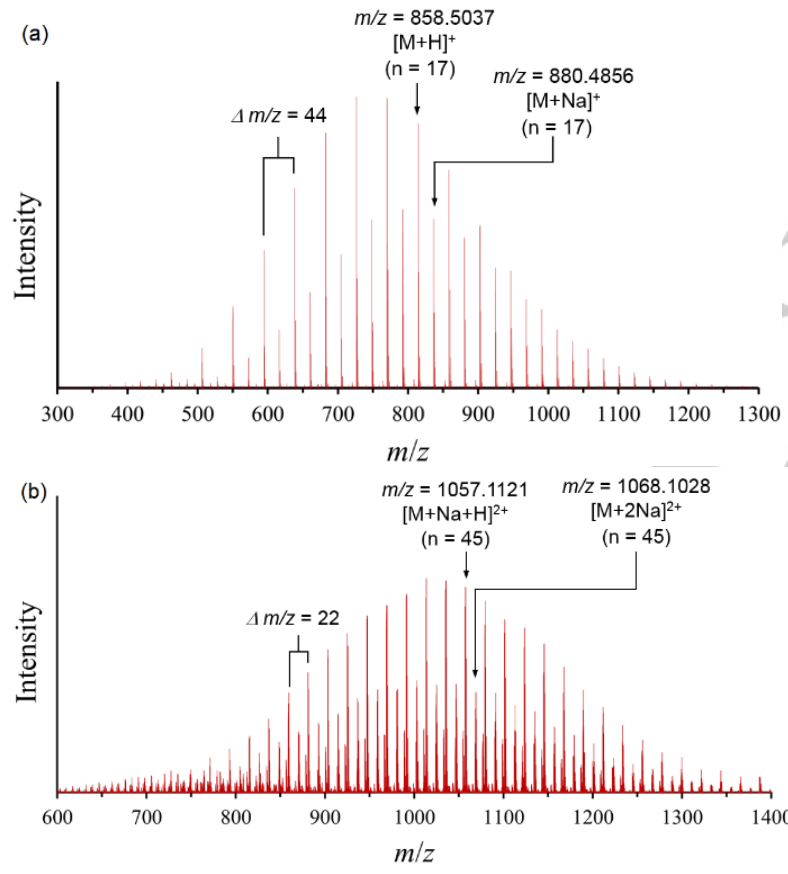

Figure 1. ESI-HRMS spectra of (a) $\mathbf{1 b}$ and (b) $\mathbf{1 c}$ (positive mode).

Coordination ability of the isolated pyridines with $\mathrm{Pd}(\mathrm{OAc})_{2}$ was investigated. The reaction of 4-methoxypyridine $\left(1^{\mathrm{OMe}}\right)$ with $\mathrm{Pd}(\mathrm{OAc})_{2}$ in toluene at $80{ }^{\circ} \mathrm{C}$ (Pyridine/Pd $=2: 1$ ) afforded $\mathrm{Pd}(\mathrm{OAc})_{2}\left(1^{\mathrm{OMe}}\right)_{2}$ that was characterized by single crystal X-ray structure analysis (Figure 2a). The Pd center has a square planar geometry and two pyridine ligands occupy trans position. This trans structure is similar to $\mathrm{Pd}(\mathrm{OAc})_{2}(\mathrm{py})_{2} .^{[13]}$ The coordination abilities of pyridine ligands bearing a PEG chain was explored using ${ }^{1} \mathrm{H}$ NMR measurements (Figure $2 b, c$ ). The reactions of pyridines with $\mathrm{Pd}(\mathrm{OAc})_{2}$ were carried out in $\mathrm{C}_{6} \mathrm{D}_{6}$ (pyridine/ $\mathrm{Pd}=$ $2: 1$ ) at room temperature. Employing $\mathbf{1 b}$ as the pyridine, after the addition of $\mathrm{Pd}(\mathrm{OAc})_{2}$, all signals attributed to $\mathbf{1 b}$ disappeared and new signals were observed (Figure $2 b$ ). This indicates the formation of $\operatorname{Pd}(\mathrm{OAc})_{2}(\mathbf{1 b})_{2}$. Notably, the similar change was observed with 1c bearing a considerably long PEG chain $(n=c a$. 45) (Figure 2c), indicating the length of PEG chains on the pyridines did not affect the coordination to the Pd center.

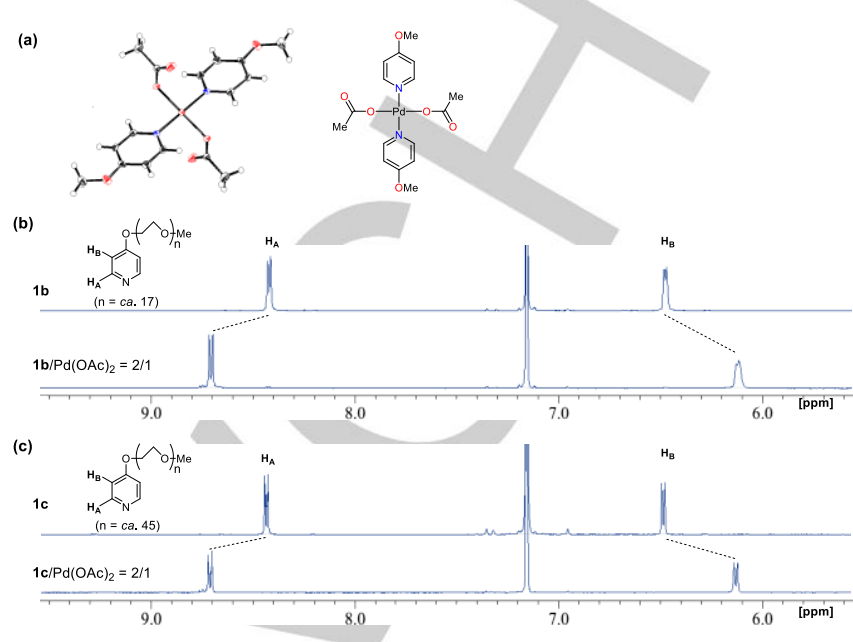

Figure 2. Crystal structure of $\mathrm{Pd}(\mathrm{OAc})_{2}\left(1^{\mathrm{OMe}}\right)_{2}(\mathrm{a})$, and ${ }^{1} \mathrm{H}$ NMR spectra of complexation experiment of pyridines with $\mathrm{Pd}(\mathrm{OAc})_{2}$ in $\mathrm{C}_{6} \mathrm{D}_{6}$ : (b) $\mathbf{1 b}$ and (c) $\mathbf{1 c}$

Next, the PEG-functionalized pyridines were used as ligands in Pd-catalyzed oxidation of alcohols. ${ }^{[11]}$ The reaction of 1 phenylethanol (4a) was performed under low Pd loading conditions $(0.30 \mathrm{~mol} \%)$ in toluene at $100{ }^{\circ} \mathrm{C}$ under an oxygen atmosphere (Table 1). Employing pyridine ligands bearing PEG chains at the 4-position (10Me $, \mathbf{1 a}, \mathbf{1 b}$, and $\mathbf{1 c}$ ), the yields of acetophenone $(\mathbf{5 a})$ increased as the PEG chains extended

Table 1. Effect of pyridines on Pd-catalyzed Oxidation of 1-Phenylethanol under $\mathrm{O}_{2}{ }^{[\mathrm{a}]}$

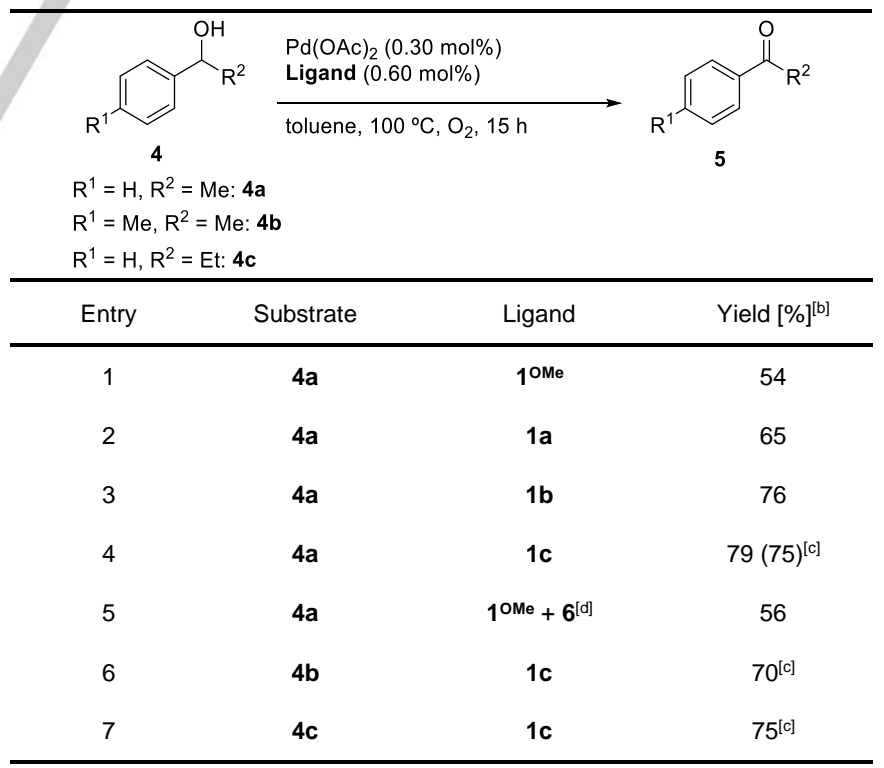

[a] Reaction conditions: 1-phenylethanol (4.0 mmol), $\mathrm{Pd}(\mathrm{OAc})_{2}(0.30 \mathrm{~mol} \%)$ pyridine ligand $(0.60 \mathrm{~mol} \%)$ in toluene $(0.60 \mathrm{~mL})$ at $100{ }^{\circ} \mathrm{C}$ for $15 \mathrm{~h}$ under $\mathrm{O}_{2}(1$ atm). [b] Determined by GC analysis. [c] Isolated yield. [d] 0.60 mol\% of 6 was added. [c] isolated yield 


$$
\begin{aligned}
& \mathrm{MeO}(\widehat{\mathrm{OO}})_{\mathrm{ne}} \\
& \mathbf{6}:(\mathrm{n}=\text { ca. } 45)
\end{aligned}
$$

(entries $1-4)$. Notably, the highest yield (79\% yield) was obtained using the pyridine having the longest PEG chain (1c, $n=45$, entry 4). From the reaction mixture, 5 a was isolated in $75 \%$ yield. Here, a simple mixture of $\mathrm{MeO}\left(\mathrm{CH}_{2} \mathrm{CH}_{2} \mathrm{O}\right){ }_{n} \mathrm{Me}(\mathrm{n}=\mathrm{ca} .45)(6)$ and $1^{\text {OMe }}$ $\left(0.60 \mathrm{~mol} \%, 6 / 1^{\mathrm{OMe}}=1\right)$ instead of $1 \mathrm{c}$ afforded the product in $56 \%$ yield, which was comparable to that using $1^{\text {OMe }}$ (entry 5 vs. entry 1). Therefore, these results clearly indicate that PEG chains must be directly connected to the pyridine moiety in order to improve the catalytic activity. From 1-(4-tolyl)ethanol (4b) and 1-phenyl-1propanol (4c), the corresponding ketones (5b and $\mathbf{5 c}$ ) were obtained in $70 \%$ and $75 \%$ isolated yields, respectively, using 1c as the ligand under the optimum reaction conditions. The reactions using other alcohols such as 2-octanol, benzyl alcohol, and 1-octanol under the optimum reaction conditions afforded the corresponding products in $16 \%, 34 \%, 2 \%$ yields, respectively

To gain insight into structure of 1c $(n=45)$, conformational analysis was performed by using CONFLEX ${ }^{[15]}$ (MMFF94 force field). During the conformational search, a large number of conformers with small energy differences were found around an energy-minimized conformer. This indicates that the PEG chain is highly flexible. Then, the energy-minimized structure was further optimized by DFT calculations (B3LYP/6-31G(d)). Figure 3a shows the optimized structure of $1 \mathrm{c}$, wherein a flexible PEG chain is folded and forms a bulky structure. Under catalytic reaction conditions with $\mathrm{L} / \mathrm{Pd}=2(\mathrm{~L}=\mathbf{1 b}$ or $\mathbf{1 c}), \mathrm{Pd}(\mathrm{OAc})_{2}(\mathrm{~L})_{2}$ must be initially generated. Thus, structures of $\mathrm{Pd}(\mathrm{OAc})_{2}(\mathbf{1 b})_{2}$ was optimized by ONIOM ${ }^{[16]}$ (B3PW91/LANL2DZ-UFF) calculation. In the structure of $\mathrm{Pd}(\mathrm{OAc})_{2}(\mathbf{1} \mathbf{b})_{2}$, a folded PEG chains covers the rear side of the pyridine ring (Figure $3 b$ ). The structure would suppress the aggregation of $\mathrm{Pd}$ species owing to its long-range flexible steric bulk.
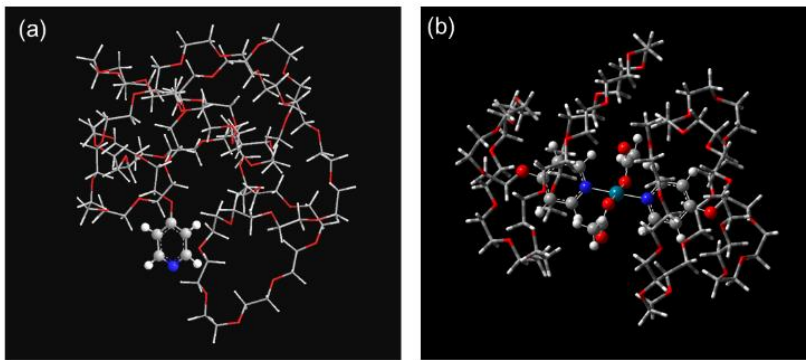

Figure 3. Optimized structures of PEG-functionalized pyridines. (a) 1c $(n=45)$. The pyridine ring moiety is shown as a ball and stick model. (b) $\mathrm{Pd}(\mathrm{OAc})_{2}(\mathbf{1 b})_{2}$ $(n=17)$. The $\operatorname{Pd}(O A c)_{2}(p y)_{2}$ core is shown as a ball and stick model.

In summary, we designed and prepared a series of pyridine ligands bearing PEG chains (1a-c) by straightforward methods using a commercially available 4-chloropyridine and PEG derivatives as starting materials. These pyridines were characterized by NMR and ESI-HRMS analyses. The pyridine ligands bearing longer PEG chains were efficient in the $\mathrm{Pd}$ catalyzed oxidation of alcohols. Conformational analysis and DFT calculations indicated that 1c has a unique and bulky structure that could suppress the aggregation of Pd catalysts in alcohol oxidation. Further studies on the position effect of the pyridine ring and application to other reactions are currently underway.

\section{Experimental Section}

Preparation of 1a: In a dried two-neck $300-\mathrm{mL}$ round-bottomed flask, 3a (4.9 g, 30 mmol, 1.0 equiv) was dissolved in THF (120 $\mathrm{mL}$ ) and the solution was stirred at $0 \stackrel{\circ}{\circ}$. To this solution, $\mathrm{NaH}(3.4$ $\mathrm{g}$ as a $60 \%$ dispersion, $84 \mathrm{mmol}, 2.8$ equiv) was added portion wise and the mixture was stirred for $40 \mathrm{~min}$ at $0 \stackrel{\circ}{ } \mathrm{C}$. After stirring 4-chloropyridine hydrochloride (2, $5.4 \mathrm{~g}, 36 \mathrm{mmol}, 1.2$ equiv) was added and the mixture was stirred for $23 \mathrm{~h}$ under reflux. The progress of the reaction was monitored by ${ }^{1} \mathrm{H}$ NMR measurements, and in order to ensure completion of the reaction the additional $2(5.4 \mathrm{~g}, 36 \mathrm{mmol})$ and $\mathrm{NaH}(1.4 \mathrm{~g}$ as $60 \%$ dispersion, $36 \mathrm{mmol}$ ) were added to the reaction mixture and the mixture was further stirred for $3 \mathrm{~h}$ under reflux. After the reaction was completed, water $(10 \mathrm{~mL})$ was added and THF was evaporated. The resulting mixture was passed through a pad of celite. The water $(150 \mathrm{~mL})$ was added to the resulting solution and the aqueous solution was washed with hexane $(150 \mathrm{~mL} \times 5)$. The resulting aqueous layer was extracted with $\mathrm{CH}_{2} \mathrm{Cl}_{2}(80 \mathrm{~mL} \times 4)$ and the organic layer was dried over $\mathrm{MgSO}_{4}$. After filtration, the filtrate was evaporated to dryness and the resulting oil was purified by silica gel column chromatography using $\mathrm{CHCl}_{3} / \mathrm{MeOH}$ $(30: 1, v / v)$ as an eluent. After removal of all volatiles, 1a was obtained in $60 \%$ yield $(4.4 \mathrm{~g}, 18 \mathrm{mmol})$ as pale yellow oil. ${ }^{1} \mathrm{H} \mathrm{NMR}$ $\left(400 \mathrm{MHz}, \mathrm{CDCl}_{3}\right): \delta 8.44-8.40(\mathrm{~m}, 2 \mathrm{H}), 6.85-6.81(\mathrm{~m}, 2 \mathrm{H}), 4.20-$ $4.16(\mathrm{~m}, 2 \mathrm{H}), 3.90-3.86(\mathrm{~m}, 2 \mathrm{H}), 3.76-3.71(\mathrm{~m}, 2 \mathrm{H}), 3.70-3.63(\mathrm{~m}$, $4 \mathrm{H}), 3.57-3.53(\mathrm{~m}, 2 \mathrm{H}), 3.38(\mathrm{~s}, 3 \mathrm{H}) .{ }^{13} \mathrm{C}$ NMR $(100 \mathrm{MHz}$, $\left.\mathrm{CDCl}_{3}\right): \delta 164.7,150.9,110.3,71.8,70.8,70.6,70.5,69.2,67.1$ 58.9. ESI-HRMS $(\mathrm{m} / \mathrm{z}):[\mathrm{M}+\mathrm{H}]^{+}$calcd for $\mathrm{C}_{12} \mathrm{H}_{20} \mathrm{O}_{4} \mathrm{~N}, 242.1387$; found, 242.1384 .

\section{Acknowledgements}

This work was supported by JSPS KAKENHI Grant Number 17 H03096 in Grant-in-Aid for Scientific Research (B) from MEXT, Japan (YT). TF acknowledged JSPS KAKENHI Grant Number $18 \mathrm{H} 04257$ in Precisely Designed Catalysts with Customized Scaffolding from MEXT, Japan. MS is grateful to a Research Fellowship from JSPS for Young Scientists.

Keywords: alcohol • oxidation $•$ palladium $•$ poly(ethylene glycol) - pyridine

\section{References:}

[1] a) L Brandsma, S. F. Vasilevsky, H. D. Verkruijsse, Applications of Transition Metal Catalysts in Organic Synthesis, Springer, Berlin, 1999; b) Homogeneous Transition Metal Catalyzed Reaction, (Eds. W. R. Moser, D. W. Slocum), American Chemical Society, Washington, 1992.

[2] Selected Reviews; a) D. J. Durand, N. Fey, Chem. Rev. 2019, 119, 6561-6594. b) D. G. A. Verhoeven, M.-E. moret, Dalton Trans. 2016, 45, 15762-15778. c) B. Sarkar, D. Schweinfurth, N. Deibel, F. Weisser, Coord. Chem. Rev. 2015, 293-294, 250-262. d) M. Raynal, P. Ballester, A. Vidal-Ferran, P. W. N. M. van Leeuwen, Chem. Soc. Rev. 2014, 43, 1660-1733. e) K. M. Engle, J.-Q. Yu, J. Org. Chem. 2013, 78, 89278955

[3] a) F. E. Bailey, Jr.; J. V. Koleske, Poly(Ethylene Oxide); Academic Press Inc., New York, 1976; b) Poly(ethylene glycol) Chemistry and Biological Applications (Eds. J. M. Harris, S. Zalipsky) American Chemical Society: Washington, D.C., 1997. 
[4] For the selected examples of PEG-functionalized ligands in water, see: a) V. Liu, Y. Wang, E. Long, Transition Met. Chem. 2014, 39, 11-15; b) K.-i. Fujita, J. Sato, K. Inoue, T. Tsuchimoto, H. Yasuda, Tetrahedron Lett. 2014, 55, 3013-3016; c) Y. Wang, J. Luo, Z. Liu, Appl. Organomet Chem. 2013, 27, 601-605; d) N. Liu, C. Liu, Z. Jin Green Chem. 2012, 14, 592-597; e) Z. Zou, Q. Ma, Appl. Organomet. Chem. 2011, 25, 233237; f) K.-i. Fujita, M. Kujime, T. Muraki, Bull. Chem. Soc. Jpn. 2009, 82 261-266; g) O. Adidou, C. Goux-Henry, M. Safi, M. Soufiaoui, E. Framery, Tetrahedron Lett. 2008, 49, 7217-7219; h) X. Wang, L. Yin, T. Yang, Y. Wang, Tetrahedron: Asymmetry 2007, 18, 108-114; i) A. Leyva, H. García, A. Corma, Tetrahedron 2007, 63, 7097-7111; j) S. H. Hong R. H. Grubbs, J. Am. Chem. Soc. 2006, 128, 3508-3509.

[5] a) B. H. Lipshutz, S. Ghorai, Org. Lett. 2009, 11, 705-708; b) B. H. Lipshutz, S. Ghorai, Tetrahedron 2010, 66, 1057-1063; c) Y. Uozumi, H. Danjo, T. Hayashi, Tetrahedron Lett. 1997, 38, 3557-3560; d) W. Mai, L. Gao, Synlett 2006, 2553-2558; e) L. Bai, L. Zhang, J. Pan, J. Zhu, Z. Cheng, X. Zhu, Macromolecules 2013, 46, 2060-2066.

[6] a) T. Dickerson, N. Reed, K. Janda, Chem. Rev. 2002, 102, 3325-3344; b) D. E. Bergbreiter, Chem. Rev. 2002, 102, 3345-3384. c) H. Han, K. D. Janda, J. Am. Chem. Soc. 1996, 118, 7632-7633. d) D. E. Bergbreiter, P. L. Osburn, Y.-S. Liu, J. Am. Chem. Soc. 1999, 121, 9531-9538. e) Q. Yao, Angew. Chem. Int. Ed. 2000, 39, 3896-3898.

[7] D. Zhang, C. Chen, Angew. Chem. Int. Ed. 2017, 56, 14672-14676.

[8] a) T. Fujihara, S. Yoshida, H. Ohta, Y. Tsuji, Y. Angew. Chem. Int. Ed. 2008, 47, 8310-8514; b) T. Fujihara, S. Yoshida, J. Terao, Y. Tsuji, Org Lett. 2009, 11, 2121-2124.

[9] T. Fujihara, T. Yoshikawa, M. Satou, H. Ohta, J. Terao, Y. Tsuji, Chem. Commun. 2015, 51, 17382-17385; b) H. Ohta, T. Fujihara, Y. Tsuji, Dalton Trans. 2008, 379-385.

[10] M. Satou, T. Fujihara, J. Terao, Y. Tsuji, Synlett 2018, 29, 556-559.

[11] Selected reviews and examples, see: a) T. Nishimura, T. Onoue, K. Ohe, S. Uemura, Tetrahedron Lett. 1998, 39, 6011-6014; b) G.-J. ten Brink, I W. C. E. Arends, R. A. Sheldon, Science 2000, 287, 1636-1639.; c) L. C. John, A. Gunay, A. J. Wood, M. H. Emmert, Tetrahedron, 2013, 69, 5758-5764.; d) S. S. Stahl, Angew. Chem., Int. Ed. 2004, 43, 34003420; e) Wang, D.; Weinstein, A. B.; White, P. B.; Stahl, S. S. Chem. Rev. 2018, 118, 2636-2679.

[12] T. Iwasawa, M. Tokunaga, Y. Obora, Y. Tsuji, Y. J. Am. Chem. Soc. 2004, 126, 6554-6555.

[13] G. Giachi, W. Oberhauser, M. Frediani, E. Passaglia, L. Capozzoli, L. Rosi, J. Polym. Sci. A, Polym. Chem. 2013, 51, 2518-2526.

[14] S. V. Kravtsova, I. P. Romm, A. I. Stash, V. K. Belsky, Acta Crystallogr., C, 1996, 52, 2201-2204.

[15] a) H. Goto, E. Osawa, J. Am. Chem. Soc. 1989, 111, 8950-9851; (b) H. Goto, E. Osawa, J. Chem. Soc., Perkin Trans. 2, 1993, 187-198.

[16] a) F. Maseras, K. Morokuma, J. Comput. Chem. 1995, 16, 1170-1179; b) S. Humbel, S. Sieber, K. Morokuma, J. Chem. Phys. 1996, 105, 1959 1967; c) M. Svensson, S. Humbel, R. D. J. Froese, T. Matsubara, S. Sieber, K. Morokuma, J. Phys. Chem. 1996, 100, 19357-19363. 


\section{Entry for the Table of Contents}

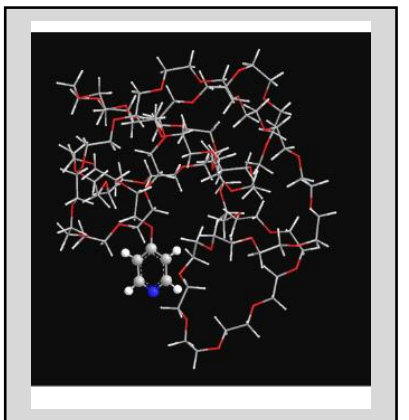

A series of pyridine ligands bearing poly(ethylene glycol) (PEG) chains at the para positions were synthesized and characterized by NMR and ESI-HRMS analyses. In the Pd-catalyzed oxidation o.f alcohols, the pyridines bearing longer PEG chains were efficient. 